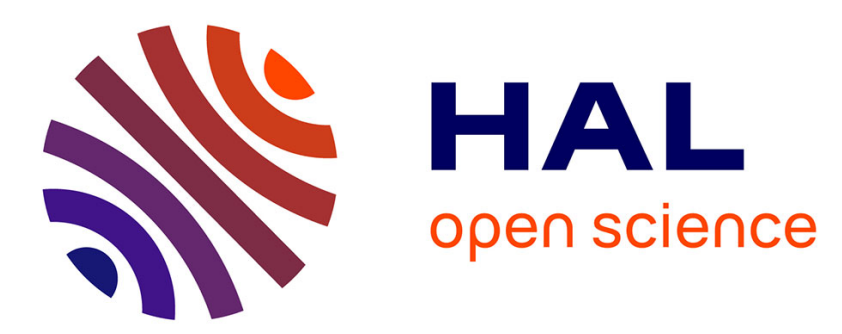

\title{
Women's Epistolary Cinema. Exploring Female Alterity and Intersubjectivity: Letter-Films and Filmic Correspondences
}

\author{
Lourdes Monterrubio Ibáñez
}

\section{- To cite this version:}

Lourdes Monterrubio Ibáñez. Women's Epistolary Cinema. Exploring Female Alterity and Intersubjectivity: Letter-Films and Filmic Correspondences. Quarterly Review of Film and Video, 2021, 10.1080/10509208.2021.1944014 . hal-03259068v4

\section{HAL Id: hal-03259068 \\ https://hal.science/hal-03259068v4}

Submitted on 25 Aug 2021 (v4), last revised 20 Mar 2023 (v5)

HAL is a multi-disciplinary open access archive for the deposit and dissemination of scientific research documents, whether they are published or not. The documents may come from teaching and research institutions in France or abroad, or from public or private research centers.
L'archive ouverte pluridisciplinaire HAL, est destinée au dépôt et à la diffusion de documents scientifiques de niveau recherche, publiés ou non, émanant des établissements d'enseignement et de recherche français ou étrangers, des laboratoires publics ou privés. 
This is an Original Manuscript of an article published by Taylor \& Francis in

Quarterly Review of Film and Video on $15^{\text {th }}$ August 2021, available at

https://doi.org/10.1080/10509208.2021.1944014

\title{
Women's Epistolary Cinema. Exploring Female Alterity and Intersubjectivity: Letter-Films and Filmic Correspondences
}

\author{
Lourdes Monterrubio Ibáñez \\ Complutense University of Madrid \\ loumonte@ucm.es \\ ORCID: $\underline{0000-0003-0566-3666}$
}

This article aims to analyse of the relevance of female authorship in the creation of contemporary epistolary cinema, focusing on letter-films and filmic correspondences. The works of various filmmakers are essential to understand the evolution of these enunciation devices since the emergence of cinematic modernity to the present moment. Since Agnès Varda represented an epistolary correspondence between women -L'une chante, l'autre pas (1977)- and Marguerite Duras created an epistolary diptych as two identity-alterity variations -Aurélia Steiner (1979)-, other women filmmakers have developed this cinematic form. Letter-films delve into epistolary seriality and materiality -Cartas visuales (Tiziana Panizza, 2005-2012,) and Envíos (Jeannette Muñoz, 2005-2017)- and deepens the concept of alterity -Elena (Petra Costa, 2012). Filmic correspondences work on emotion-image -This World (Naomi Kawase and Hirokazu Kore-eda, 1996), In Between Days (Naomi Kawase and Isaki Lacuesta, 2009)- and shows female intersubjectivity -Correspondencia: Fernando Eimbcke - So Yong Kim (2011), Life May Be (Mania Akbari, Mark Cousins, 2014), A Moon for My Father (Mania Akbari, Douglas White, 2019), Transoceánicas (Meritxell Colell Aparicio, Lucía Vassallo, 2020). Women's letter-films and filmic correspondences delve into the exploration of intimate space, authorial vindication and epistolary materiality, in order to create diverse experiences of female alterity and intersubjectivity.

Key words: women's cinema, epistolary cinema, letter-film, filmic correspondence, alterity, intersubjectivity. 


\section{Introduction}

This article aims to analyse how women filmmakers explore the possibilities of alterity in epistolary cinema-letter-films and filmic correspondences-regarding female identity, subjectivity and intersubjectivity. It offers an itinerary along a numerous corpus that traces the evolution of the epistolary device as well as the relevance of these films both from the point of view of cinematic language and female identity. Women's epistolary cinema starts from three key epistolary works by three francophone filmmakers who, in the space of three years, offer three crucial works in the evolution of this enunciative device, and use it to generate a female discourse: L'une chante, l'autre pas (Agnès Varda, 1977) through the correspondence inside a narrative in which the filmmaker places herself as an intermediary narrator; Aurélia Steiner (Marguerite Duras, 1979) using the letterfilm in which the author becomes a fictional performer; News from Home (Chantal Akerman, 1977) creating a new form, the epistolary film, in which the filmmaker is the documentary subject. The three films are the starting point of a deep relationship between female authorship and an epistolary cinema which proliferates in contemporary space (Monterrubio Ibáñez 2019a) through its different possibilities: letter-film, filmic correspondence, epistolary film and epistolary essay film.

The innovation of L'une chante, l'autre pas in the space of "the modern representation of epistolary enunciation" (Monterrubio Ibáñez 2018, 189-260) is to abandon the amorous topic -which has its greatest representation in the works of Truffaut: Jules et Jim (1961), Les Deux Anglaises et le Continent (1971), L'Histoire d'Adèle H. (1975)- to inaugurate an epistolary writing between women that becomes an experience of sisterhood and a space for feminist reflection, thus initiating the relevance of the postcard in Varda's work (Bluher 2019). The analysis of the feminist discourse it contains (Sandy Flitterman-Lewis 1996; Hottell 1999; DeRoo 2009) must also extend to the specificities 
of its epistolarity. The relationship between Pomme and Suzanne is not only narrated but developed through an epistolary correspondence that began in 1972, 10 years after they met, when they come across in the mobilisation around the Bobigny process. After sharing Suzanne's abortion and the suicide of her partner, Jérôme, in 1962, the encounter provokes an epistolary longing in both characters:

- We'll write, you think?

- Oh, yes, long letters.

This desire, and this is the first innovation, is materialised through a new epistolary dynamic: the epistolary reverie, a sort of mental dialogue with the addressee that enables or at least facilitates feminist awareness. Varda herself uses her voice-over to account for this process: 'Suzanne thought of Pauline, now Pomme. She wanted to tell her about her life, as if she had to. Because of what they'd been through,' 'And Pomme also thought of Suzanne'. This desire not only activates the reflection of both protagonists, but they become film narrators through it; we listen to their voice-overs along with the image representation of the epistolary content. Suzanne's first two epistolary enunciations take place in the return train journey after the meeting, in the need to tell her friend about what happened in her life during the ten years of absence. Only in the conclusion of the second fragment, the epistolary act and its enunciation situation is mentioned: 'I send you a photo [...] I have no time to write. Only a few words on a postcard.' Thus, the postcard correspondence is testimony and synthesis of a crucial mental epistolarity in the evolution of both women, which is possible thanks to the existence of the addressee: 'Pomme and Suzanne are not solely addressing each other in writing but also in their thoughts' (Bluher 2019, 295). Suzanne's first two epistolary fragments respond to that same mental realisation, turned into a space for reflection. Varda intervenes again to describe the nature of this epistolary potentiality: 'But she and Pomme made an air-mail bridge, a quiet 
imaginary dialogue punctuated by postcards'. The filmmaker thus chooses to place herself in a 'intermediary position', acting as 'shifters or translators between diegetic characters and between film and audience' (Naficy 2001, 111), in order 'to establish a connection between herself and the film, between herself and the spectator' (Hottel 1999, 60). In this way, the deferred epistolary dialogue becomes a mental dialogue that finds in the postcards a kind of material proof, a synthesis of the mental epistolarity realised, and a testimony of the ideological evolution to which it contributes, of the sisterhood experience of two women in the distance. This process from the mental to the material is shown in Pomme's third, fourth, and fifth epistolary enunciations: from the mental epistolarity which leads the image narration; to the postcard in which it materialises and that is displayed on screen when Suzanne receives it; and back to the mental epistolarity, which does not stop. The same process occurs with Suzanne in the fifth text and her postcard writing in the sixth, the latter shown again when Pomme receives it.

This mental epistolarity expressed through the voice-overs of the correspondents, and that convert the visual image into representations of its content, is not only 'a measure of the profoundness of their friendship' (Bluher 2019, 295) but also a certification of a $I$ keep thinking about us and what is more a I keep thinking us as women. The synthesis of everyday life not only vouches for that essential mental epistolary activity, but also informs about the needlessness to be held accountable of it. Thus, this mental epistolarity implies the creation of a safe space for reflection, essential for the construction of the vital discourse that both women sustain in the real world:

As a director, Varda is interested in questions, not answers. For feminists concerned with meanings and with films, this implies grasping the political power of those questions. It means seeing those questions not as limitations, which is how traditional masculine hierarchies of value understand them [...] but as options that allow the productive engagement in the act of questioning itself (Flitterman-Lewis 1996, 314). 
Two years later, Marguerite Duras used the letter-film to create an absolutely new limit experience of modern cinema, regarding the relationships between literature and cinema in Aurélia Steiner (1979). Both letter-films, Melbourne and Vancouver, materialise in the Deleuzian time-image and the Durasian subjective non-representational cinema (Monterrubio Ibáñez 2018, 130-188), beginning the practice of an epistolary seriality, very scarce, which will have its extension in other women filmmakers, as will be analysed below.

Duras carried out the identity search of the two Aurélia Steiner through the destruction of the epistolary device by problematising its different elements (VoisinAtlani 1988). The addresser is devoid of ipseity; the addressee is likewise an emptied identity in Melbourne and multiplied and confused one in Vancouver; the situations of enunciation are omitted in order to be also fictionalised through the final lines of both letters, in which only the name of the city varies, using them to differentiate their titles. The filmmaker then creates the time-image of a non-representational cinema thanks to the literary-cinematic coalescence generated by the independence between the sound image and the visual image; the interstice between them; their free indirect relationship; the voice of the sound image as a pure act of speech; and the spatial and temporal disorientation. In this way, the filmmaker manages once again to 'give shape to the absence' (Ishaghpour 1986, 273), in this case epistolary shape. An eternal present is then generated to enable infinite fabulation. The presence-sound of Aurélia-Duras' voice and its absence-image are addressed to an other, unknown or multiple, imagined and fabled, to generate metaphorical correspondences between visual image and sound image that exponentially elevate the capacities of invocation, reverie, fabulation and poeticity of both disciplines separately. 
In Aurélia Steiner - Melbourne, the epistolary voice-over becomes a callinvocation to death, to infinity, that deepens its meanings when confronted with the visual image of the Seine, generating an interstice where absence sustains. The destruction of ipseity, which materialises in the sound image, could appears for a few moments in the visual image, by showing a young woman on a bridge, who silences the epistolary Ivoice, that we cannot avoid to link with the protagonist. Thus, the idea of the dissolution of Aurélia in all beings and all places would concretise, as the filmmaker explains:

And I believe that, at one point, Aurélia Steiner is on a bridge [...] I believe that it is her too, Aurélia Steiner. She will never know. She is there, or elsewhere. That is it. She is broken. In pieces. Disseminated in the film. Drowned. And she is entirely there, at the same time. Impregnable, indestructible [...] Here, as elsewhere, like all Jews (Duras and Noguez 1984, 184-185).

In Aurélia Steiner - Vancouver the literary-cinematic coalescence is confirmed as a metaphorical creator of enormous poetic power, expressing a failed search for identity. Aurélia alternately addresses her parents, both dead in the concentration camp where she was born, coming to identify the father with the sailor-lover whom he also addresses, in order to make them pronounce her name, to give her identity. This longing for filial and love identity is revealed on the cinematic screen when inscribed on it, followed by her camp identification number. The ability of the letter to combine the enunciative and the representational question of the epistolary self makes Aurélia Steiner the culmination of the complexification of the concept of ipseity and the destruction of the epistolary device. These letter-films, therefore, destroy the literary narrative and the cinema of prose to build from the prose poem and the cinema of poetry, under the irrationality that defines both expressions. While Varda placed herself as an intermediary for her female fictional characters, Duras explores identification with hers to enunciate a female subjectivity that 
addresses the expression and search for identity regarding a deep exploration of the themes of origin, desire and death.

After these epistolary creations belonging to modern cinema, the advent of postmodernity implies the hegemony of the concept of alterity, as many authors analysed, pointing out the relevance of alterity in identity. Julia Kristeva explores how 'disturbing, strangeness is within us: we are our own strangers, we are divided' $(1988,269)$. Zygmunt Bauman analyses it through the concept of strangeness, understanding it as 'the existential and mental ambivalence' $(1991,95)$ universalised in postmodernity. For his part, Marc Augé uses the concept of intimate alterity to describe it as a "necessity at the very heart of individuality, prohibiting at the same time to dissociate the question of collective identity from that of individual identity' (1992, 29-30). Paul Ricœur establishes three modalities: 'proper alterity, alterity of the other, alterity of consciousness,' through which he describes and studies the complexity of this 'ontology of alterity,' $(1990,410,373)$ allowing us to understand the dialectics between ipseity and otherness. The idiosyncrasy of the epistolary device lies in offering a unique space for expressing and exploring that 'existential and mental ambivalence', that 'intimate alterity', that 'alterity of conscience' of the addresser in relation to the addressee. It becomes then an ideal tool in the cinematic field to explore the experience of alterity, materialising this paradigm shift in filmic creation. Besides intimacy, self-expression, the border between private and public spheres and, of course, the digital revolution as reasons for the proliferation of epistolary enunciation in contemporary cinema, I argue that it is the necessity to explore the alterity experience the nuclear reason of the proliferation of the epistolary device and also of the multiplicity of its forms, since it becomes a powerful ontological instrument to this purpose. The three films mentioned express, reflect and vindicate female subjectivity thanks to the experience of alterity, and other women filmmakers has been able to 
continue its exploration. I will analyse the most notable works made by female filmmakers classified regarding two practices: the letter-film and the filmic correspondence. While letters films start from the dialectics between ipseity -proper alterity- and otherness - alterity of the other-, the filmic correspondence have the option to work on the intersubjectivity, as Isabelle Thomas-Fogiel defines it:

This space of the we is not the addiction of the $I$ and the you, but the intersection of several perspectives, the place where sharing glances, the moment of intersection [...] thinking about intersubjectivity means thinking about this enriching intersection, creating each time, through encounter, the sphere of a new we [...] I aim at the other and the other aim at me and what must be studied under the name of intersubjectivity is the intersection of these aims (Thomas-Fogiel 2014, 384-385).

\section{The letter-film: intimate space and epistolary seriality and materiality}

The exploration of epistolary seriality started by Duras with the diptych Aurélia Steiner did not continue until the work of another women filmmaker already in the 21 st century.

Tiziana Panizza generates an epistolary trilogy, Cartas visuales (2005-2012), unique in contemporary cinema. On this occasion, the epistolary writing is personal, that of Panizza herself. She not only explores epistolary realisation in its temporality, generating three missives over eight years, but also places them on the two sides of her exile experience, responding to the characterisation offered by Hamid Naficy: '[E]xile and epistolarity are constitutively linked because both are driven by distance, separation, absence, and loss and by the desire to bridge the multiple gaps' $(2001,101)$, and its aspiration of presence: 'The very fact of addressing someone in an epistle creates an illusion of presence that transforms the addressee from an absent figure into a presence, which hovers in the text's interstices' (103). The three letter-films are made in Super-8mm, making its materiality the fundamental interstice of the work, as Paola Lagos Labbé analyses (Figure 1): 
[T] he poetics of the Super-8mm as an interstitial image is shaped on the awareness of the ineffable and intangible, that is to say, of the immanent character of the real, irreducible to an image [...] the Super-8mm would seek here to reveal the tensions between the representable and the irrepresentable; between the nameable and the implicit $(2015,167)$.

The epistolary materiality of the film, which also becomes a metaphor for memory, is analysed by Irene Depetris (2017) in relation to the haptic visuality theorised by Laura U. Marks (2000), as a procedure to 'build a gaze and a listening' (Depetris 2017, 455). For her part, María Paz Peirano (2018) studies the film in relation to the subjective turn (Renov 2004) and autoethnography (Russell 1999).

Figure 1. Al final: la última carta (Tiziana Panizza, 2012) (C) Tiziana Panizza. Courtesy of the filmmaker.

Panizza's trilogy is also inscribed in a 'phenomenology of filmic letters' that shares with Duras 'the potentiality of assuming an imaginary in motion to use it in one's own imaginary $[\ldots]$ an environment, an atmosphere to be inhabited by the interlocutor' (Català 2019, 280, 283). In this case, this imaginary is generated from the multiplicity of enunciations -voice-over, intertitles, texts in image, music- that realise a kind of unprecedented epistolary glimpses, indebted to the practice of Jonas Mekas, only comparable to Jeannette Muñoz's Envíos and to Lettre de Joseph Morder à Alain Cavalier (Joseph Morder, 2005). It is crucial then to analyse the achievements of this new epistolary seriality, which addresses identity through a female alterity, her grandmother. The first two letters are configured as a mirrored diptych of the two exile positions, while the third becomes a kind of synthesis of the previous ones and their projection into the future. It is necessary to point out different crucial elements of the dialogism of the first two letters. In the first place, the missives are generated from the prolongation of the family epistolary rituals that Panizza now converts into audiovisual ones: in the first, Dear 
Nonna: A film letter (2005), her grandmother's habit of reading for others the letters that came from Italy after her exile; in the second, Remitente: una carta visual (2008), the letters the filmmaker wrote when she was a child to that unknown Italian family. Secondly, as already indicated, the two missives are generated from both spatial and temporal sides of exile. The first from London to her grandmother in Chile; the second already from Chile, after her return, to the Italian family she never knew. The missive from exile focuses on the addressee, while the return one focuses on the addresser. The first is created from the desire for memory and the second on the analysis of forgetting. The first is based on the personal archive and the second uses found-footage. The first is generated in the language of exile and the second, although it includes some sentences in Spanish, loses the opportunity to have explored this dialogism also from the linguistic perspective. Therefore, this enriching dialogue between both letter-films reveals an identity expression through the exile experience and the return; and also through filming and motherhood in the third letter-film. Al final: la última carta (2012) offers a legacy letter addressed to her son -as was the case in Nuages: lettres à mon fils (Marion Hänsel, 2001)-, in which the topics of the correspondence are synthesised, generating a kind of emotional exile. Panizza then uses the epistolary image of the message in a bottle: 'a message adrift sailing without urgency towards the future.' Therefore, motherhood turns Panizza into a memory depository: 'Today my grandmothers live a time without memory and my son still cannot keep memories. This documentary is also a letter to the future, it contains the only record of this moment,' and reflects on its relationship with filming: 'Filming to forget what I did not film, what is between shots, the invisible ellipsis between shots, what the cut hides [...] Everything happens in this moment and in infinity.' The filmmaker's identity shows its evolution throughout the eight years that elapse between them, intimately linked to the female family experience through the grandmother, to her 
own experience modified by motherhood, and also to its insertion in the social and political space.

For her part, Jeannette Muñoz marks an unprecedented new milestone in audiovisual epistolary seriality with Envíos (2005-2017). They are 34 short silent pieces in $16 \mathrm{~mm}$ and, and sometimes unique frames (10 of them), that the filmmaker makes for different addressees, both from her personal and professional environments, and which she describes: 'each one of the shipments is born from me and goes to someone, I know the person who will receive it, but they are not about me. It is not my personal biography that I am interested in telling. They are experiences, memory' (Aguado, Algarín Navarro and García 2017, 48). The series is arranged in chronological order, from Envío 1 in 2005 to Envío 34 in 2017, evidencing the relevance of the autobiographical aspect and insisting on the intimate perspective already analysed in Panizza: 'the ambiguity of the private and the public, of the autobiographical and the historical, are latent in my work' (58). Muñoz delves further into the analogical and fragmentary material aspect of this audiovisual epistolary seriality, which confirms the epistemology of non-manipulation and the filmic gesture of relinquishment of various filmeurs:

[F]ilmic experience developed in solitude, in which the filming becomes a corporal and aesthetic act characterised by subjectivity, privacy, immediacy and observation [...] these experiences of reality go beyond the diaristic or autobiographical practices, since the narration is relegated in favour of the present and spontaneous experience of placing oneself within the act of filming (Monterrubio Ibáñez 2019c, $55)$.

The shipments are mainly built through camera montage that is sometimes minimally corrected on the assembly table, and which is justified in its fragmentation: "I 
realised that fragmentary work could be a concept in itself" (Aguado, Algarín Navarro and García 2017, 60). In addition, the filmmaker addresses more than one shipment to some addressees, which enhances the idea of the permanence of the epistolary relationship over time: two addressees receive three shipments and another seven receive two. The shipments do not wait for an answer and thus differ from the filmic correspondence that I will analyse below: "I do not expect an answer [...] it is a letter thrown to the wind. The private launched into the public" (47). The project is created around two crucial concepts. The filmmaker herself describes that of community, which is particularised in the shipments addressed to other filmmakers: "It is something open, free, existing, we do not have to form a group or something similar: we just have to communicate" (46). This community appeals to the second concept, the intersubjective work:

[B]y sending to an addressee a filmed experience of my own, I felt I was somehow updating the past. If I manage to bring or, so to speak, return to someone part of my experience in the form of a film, it will result in a very special experience (47).

Among the 34 shipments, almost a third are addressed to other filmmakers, to members of that community: Ute Aurand, Claudia Schnid, Helga Fanderl (2) Reinhardt Schulz, Varinia Canto Vila, Annette Carle (2) and Robert Beavers. Envío 23, addressed to the latter, is especially significant in the apprehension of the present, in the poetic expression of temporal transience (Figure 2), which creates a 'poetics of intermittence' (Grennberger 2017, 165) through seriality and time. Fanderl writes about the shipments addressed to her. About the first one, Envío 8, she explains:

The way you are filming the meerkats reflects my cinematic approach to animals [...] as well as the way I film them [...] We see what you saw and made visible in the moment of filming and at the same time how you remember my cinematic vision (Fanderl 2017, 148-149). 
Figure 2. Envío 23 (Jeannette Muñoz, 2010) () Jeannette Muñoz. Courtesy of the filmmaker.

About the second, Envío 24, she adds: "This blank and white film signifies another kind of dialogue between you and me" (Aguado, Algarín Navarro and García 2017, 149). The recipient thus confirms the intersubjective work that interests Muñoz, the experience of including in the shipment some specific aspect of the addressee's gaze. Fanderl reveals another aspect of this seriality that undoubtedly identifies Muñoz's work with the essence of Agnès Varda's postcards (Bluher, 2019): “Thank you for your Envíos 8 and 24, this wonderful gift of your friendship!" (Fanderl 2017, 149-150). It is possible to apply to Muñoz most of the theses presented by Bluher, where the postcards, in this case the shipments, become gifts, as Broomer also explains:

Her project literalizes this act of giving, this film made for/to friends or family and packaged in dedication, a gesture that recognizes, first, that film gives us a means by which to share perception, but more, that those experiences are enriched and made meaningful in the act of gifting (Broomer 2017, 127).

The letter-film can reach the highest levels of depth in the intimate space when they address a loved one who traumatically passed away. A specific female alterity, the sister, is the motivation of two letter-films. While Lettre à ma soeur (Habiba Djahnine, 2006) pursues the sister's identity -a feminist activist murdered after a demonstrationfrom a more canonical documentary form, focused on collecting the testimonies of the people who knew her; Petra Costa performs an innovative and fascinating immersion in intimate space in Elena (2012), a letter-film addressed to her sister, who committed suicide at the age of 20 , when Costa was only seven. The letter is constructed through an experience of epistolary alterity -deepening the alterity of consciousness described by Paul Ricœur- that is again unprecedented, since the addresser is physically transfigured into the addressee in order to, from that identity (con)fusion, express the nature of the 
bond with the absent sister. The epistolary enunciation is then generated in the present of the New York city night to address Elena through Costa's voice-over in order to tell their story. It mixes present and past enunciation and also both voices, using Elena's sound letters and diaries recorded during her stay in that same city. Thus, the film shows the need to make the missive a kind of regression to pursue the identity of both sisters and discover the way in which the absent continues to inhabit the addresser: "But I return to New York, hoping to find you in the streets."

The letter thus emerges as the enunciation of that transfigured and furtive addresser, present in the images that hide her instead of showing her. Her gradual and progressive self-portrait visually achieves the resolution of the trauma that the letter exposes. This elusive identity fusion gives way to Elena's first two sound letters after her arrival in New York in 1990 to continue her acting career. These luminous letters addressed to the family in Brazil will be transformed into fragments of a desperate diary, due to mental illness, that can no longer reach any recipient. In this way, not only a dual self-portrait is presented, which must be unravelled, but also two epistolarities. Twenty years later, Costa is now trying to understand, as an adult, her sister's words, in a deferred epistolary dialogue, not only between life and death, but between childhood and adulthood. The filmmaker recounts the family story from the images of Elena's own video camera, given on her thirteenth birthday, which show the family memory of Elena's adolescence and Petra's childhood. Costa manipulates the domestic archive when Elena's image appears. She stops at it as a space for prefiguration of the epistolary dialogue, addressing the missing sister in the present through her image: "You spend afternoons directing me, acting, creating things." The missive chronologically traverses a time of the narration that alternates with the present time of the enunciation, that New York night in which Costa continues to search for her sister and herself: "I look for you." That is, to 
create the self-portrait that contains them both. This swinging between the scrutiny of the past images of the sister and the search for a new present image, a self-portrait, arrogates all the possibilities of image manipulation to express the depth of the conflict it faces. The narrative of the suicide will turn the mother into the third fundamental piece of the letter, again a mother's alterity as a crucial element in these female epistolarities; the only adult witness of the horror occurred. It is she who expresses the core of the epistolary search: "You look like her, I sometimes call you Elena," especially when she gets past her sister's age: "Now you're older than Elena." The attempt to draw the limits of that identification, the search for the present self-portrait, is then linked to Elena's voice. It explains the representative transit from the letters to the diary, to the impotent monologue: "I'd love my Dad, Mom and sister at home with me now," which is identified with the search for a self-portrait that flees, escaping on the subway windows. This search is intensified when it is Costa herself who holds the camera to film its faint shadow in the night. The suicide account intensifies the link between Elena's past words and the present identity search; Costa's self-portrait becomes clear then: "an awareness of the fear, of the lack of love of myself, my voice" without abandoning the self-filming of her own shadow, also as a configuration of dissociation: "The world is empty, deserted, it's not waiting for anyone. You're alone, completely alone. So, what are you going to do? I'll degrade myself and go down this drain. Now, I'm getting in it. Good."

Elena's farewell letter, the first and last written missive, appears on camera to highlight its materiality. It is now Costa's voice who reads her sister's words, while the image shows us her gaze on it: "I give up. I give up because my heart is so sad I feel have the right to no longer wander with this body that occupies space and keeps on shattering what I have that's so very fragile." Costa's letter-film thus contains the reading of his sister's letter as a crucial element of it. Again, the epistolary reading between women, 
these forms of female alterity, is key to the creation of epistolary forms of enormous relevance and significance. The black image ends the letter: "I want to disappear. This time I'm not supposed to fight." Costa continues with the narration of the childhood trauma suffered and the need for an identity search, in relation to Elena's image, as a consequence: "I look at myself in the mirror and don't see anything behind my eyes,' 'What's my part in this film?" The filmmaker's own epistolary question seems to have two answers. First, to generate a visual poem of the loss, in which, once again, the female alterity is protagonist. Then, and finally, the self-portrait emerges and materialises the bond with her sister, by showing herself dancing in that city night in the same way Elena would: "Memories go with time, they fade. But some find no solace, just bits of relief in the small openings of poetry. You are my inconsolable memory, made of shadow and stone. From it all is born and dances" (Figure 3).

Figure 3. Elena (Petra Costa, 2012) @ Busca Vida Filmes. Courtesy of the filmmaker.

\section{The filmic correspondence: from emotion to reflection, from subjectivity to intersubjectivity}

Within the scarce production of filmic correspondence, women filmmakers have participated in their most relevant realisations, including an epistolary correspondence between two female filmmakers, recently released: Transoceánicas (Meritxell Colell Aparicio and Lucía Vassallo, 2020).

Naomi Kawase has participated in two filmic correspondences. The first with Hirokazu Kore-eda in 1996, This World, and the second with Isaki Lacuesta in 2009, In Between Days. Kawase and Kore-eda met at the Yamagata International Documentary Film Festival in 1995. There, the project of an Super-8mm filmic correspondence arises and it would be exhibited at the Yokohama Museum of Modern Art. Therefore, compared 
to the two previous correspondences, carried out by experienced creators with a personal relationship (Terayama and Takinawa, Kramer and Dwoskin), we are in this case before a correspondence of two budding filmmakers who do not know each other. As Jordi Balló indicates, in these cases letters can become "vehicles for the discovery of the other" $(2014,317)$.

This World thus consists of six letters, three from each author, which take place between December 1995 and the arrival of spring. Kawase's missives are constructed as emotion-letters. The first one delimits this emotional dimension, rejecting narration and relegating reflection. The sound recording of Kore-eda's answering machine, on the black image, gives way to the addresser's audiovisual message. On a metal fence turned into a musical stave and under a sunny sky, we heard the filmmaker's voice-over: "December the $3^{\text {rd }}$. Fine weather. The anniversary of my grandfather's death. I visited his grave." Beethoven's Hymn to Joy is then accompanied by three detail shots of incense and flowers on the grave, followed by several shots of dried kakis associated with the memory of the grandfather. Next, a second block generates a reflection-image, which is an exception in her three letters. A close-up, without ambient sound, shows the filmmaker drying her hair in front of the mirror and then directing her gaze to the camera. In other words, subjectivity-subject is transformed into subjectivity-object; a new expression of female alterity thanks to epistolary practice. Kawase's voice-over, also transformed, imposed and whispered, uses the sound image to materialise that same transformation of subjectivity: "The towel my grandmother washed it smells of the sun. What would a towel Naomi washes smell of?" Next, a third block generates an emotion-image about childhood: the sound image of a children's choir and the visual images of a sunset and of children playing. Besides, another silent image is inserted. With the camera in one hand and chalk in the other, Naomi writes on the ground: "Grades 1-5 Elementary School. Naomi." In its 
conclusion, Kawase's fake voice we heard previously resurfaces again: "I want to meet you, I want to see you." In her second missive, Kawase goes deep into the show of intimacy. Her voice leaves a message on Kore-eda's answering machine, while the image, in semi-darkness, runs through the detail of some suspended clothespin, a metaphor for the vulnerability the filmmaker shows: "Hello, this is Naomi. How are you doing? It's been four months since we met there in Yamagata. Time has passed so quickly. Only four months? Or rather, four months already?" The letter then resumes Kore-eda's reflection on the action of looking (versus showing), into which Kawase once again inserts the subjective emotion that transforms the image. Besides the document-image of a woman at a crossroads, Kawase opposes the emotion-image of that same urban space, generated through its manipulation (slowing down and freezing, absence of sound, alteration of colour). Next, she entrusts the camera to another person to make her portrait, showing herself spontaneously: taking off the camera to show oneself in front of it is a further step in this intimate exploration. The filmmaker also adds a kind of recreation in it, with the slowing down of the last images before concluding the letter with a simple "Goodbye." In her third letter, she offers the opposite image to that of her previous one; not herself filmed by a loved one, but instead she filming her friends in close-ups while asking them to pronounce her name. Once again, Kawase captures the spontaneity of his intimate environment, a space of play and carefreeness, of emotions, totally disconnected from any reflection. Next, she shows a series of detail shots alongside, again, the melody of a singing children's choir. The last shot of Kawase's correspondence is a new inscription from her own hand, in this case on the foggy window: "I'm home."

In Kawase's second correspondence, In Between Days, this time with Isaki Lacuesta, the initial premise is repeated: an epistolary correspondence is proposed to her with a filmmaker she only met once during a festival. The project is designed as an 
exchange of four missives (two from each author) that will be presented in a discussion between the two (Cinergies, September 2009), where a joint filming, done in the days prior to the debate, will also be screened. For the first time, a correspondence removes the voice-overs of the correspondents and are replaced by the written text on the screen. Kawase makes a poetic use of it, placing it at the centre of the image to vindicate its relevance. Thus, the text is defined as an expression of identity, while the image, with its direct sound, aims to capture that poeticity from reality. Kawase's first letter is an expression of her spirituality. The images of a night prayer become the prayer that Kawase offers to her family and especially to her son, Mitsuki, who appears in the image at different times: "His name is 'light' / My blood runs through his veins / His father name is 'big-light' / They brought light into my life [...] I can't exist without them [...] Thank you for having come to this world." As Anna Petrus (2011) indicates, the letter accounts for the paradigm shift that occurs in Kawase's filmography after the birth of her son, which turns the darkness of maternal and paternal absence into the light of her own and present family. Her second letter is the update of her last missive in the correspondence with Kore-eda. While then her young friends spoke her name in front of the camera, now it's the filmmaker's current environment which does it: the workers of her film production office and the members of her family. Thus, an emotional realisation of what she has achieved in twelve years emerges; the relationships built, to which Kawase asks for the same gesture; to look at the camera, pronounce her name and add what they want. That demand to the other persists and Kawase expresses it in the text: "I am here, surrounded by my friends. At midnight, I am here, alone. It's raining. Where are you know?" A cross-fading montage of all the faces shown serves as answer: "I'm here." Once the correspondence is completed, the filmmakers meet only a few days later for their presentation to the public and the filming of the last joint letter. This is finally done in 
16mm (Kawase had proposed the Super-8mm format), in Lake Banyoles, but a technical error causes all the material to be veiled. It is this unforeseen circumstance that spontaneously provokes the prolongation of the correspondence and the irruption of intersubjectivity. Thus, Kawase's last letter offers "what he remembers": her son's childhood experience of that shared journey, in a sort of collage made up of Mitshuki's photos, Kawase's and the moving image of the lake. Opposing human experiences detained in time (still images), Kawase adds the moving image of the lake, retaking its importance in Lacuesta's imaginary to, perhaps, perpetuate it in her son's imagination. On the final black image, it is Mitsuki's voice -for the first time an epistolary voicewhich says goodbye: "Good night, see you later." While the in the first correspondence Kawase's identity is defined by her youth and spontaneity, the second one revolves around family and motherhood, evidencing her intimate evolution.

Correspondencia: Fernando Eimbcke - So Yong Kim (2011) is located in an interesting border between the shipment analysed in Muñoz's work and the epistolary exchange, due to a first and crucial characteristic. These audiovisual missives renounce the textual enunciation, or more specifically, separate it from the images. Only a few epistolary words appear on an initial black image, in order to introduce the audiovisual delivery. Unlike Muñoz, whose premise was precisely the intersubjective work in relation to the addressee of each shipment, Kim does not address this space. Eimbcke's letters suggest her topics from which she creates a subjective expression that, then, works on the intersubjectivity with her family. And, in this sense, the filmmaker's missives, like those of Kawase, are marked by motherhood. Of the four letters, the first two are made before the birth of her second daughter and the last two immediately after.

The first letter takes the idea of the fugacity and fragility of the natural environment proposed by Eimbcke's to create a piece that links the transience of a sunset 
shown through a series of still images to a sound image that brings together animal roars and a heartbeat that can evoke that of Kim's daughter still in her mother's womb. Thus, the filmmaker shifts her point of view to approach another, in this case a human being before birth. In her second letter she insists on this intersubjective search in this case in relation to her partner. While the sound image offers his voice telling about his childhood and his memories of his father, the visual image shows a detail shot of his hands, from a camera position that again approaches the subjective position. This image alternates with city images of Berlin, reduced on the black image, evoking their status as future memories, in relation to the character's words. In the last shot of the hands a new presence emerges, that of their daughter, moving the character from memories as a son to the present as a father. The third letter shows the cradle of the filmmaker's new born daughter, in which we listen to her and only see her fleeting hand or foot. The intersubjective work tries now to apprehend the new presence and intuit her new gaze on the world. Finally, the last piece shows the exterior view from the window already shown in the previous letter, in which a huge crane appears. The sound image creates a new displacement of the point of view; a last attempt at intersubjectivity that encompass the previous ones. We differentiate two sound layers. In the closest one the presence of the baby continues. From a distant second the family rumour of the rest of its members arises. This provides a sound portrait of the filmmaker's family and the world in which her home is situated. Thus, her letters made an intersubjective itinerary from her still no born daughter and her partner and daughter, to the new born and finally the complete family.

Life May Be (2014) shows the correspondence between Mark Cousins and the Iranian filmmaker Mania Akbari, in which the question of cultural identity and its link with artistic creation is protagonist. The first letter of the three from Cousins is the rereading of a past letter published with the DVD edition of One.Two.One (Mania 
Akbari, 2011): an imagined journey through cities and movies to which the addresser relates the addressee's cinema, and which concludes with an exciting comparison between the filmmaker and Virginia Wolf: "So let's end our journey together outside Virginia's old home [...] Let's take a picture of you and it on our camera phones and see in that picture a great artist [...] I love travelling with you, Mania." Saying goodbye in the present of the enunciation Cousins adds: "So that's was the letter, Mania [...] It turns out that you did read it. How do I know? Because of this picture." A photo of Akbari at the door of Woolf's residence ends the missive. In her first letter, Akbari goes back to the imagined journey drawn by Cousins to offer a real one, that of Akbari's exile. To the static image of the landscape of her correspondent, Akbari opposes a missive built almost entirely with still images, and her also crucial voice-over. The letter begins with images of the landscape of Meygun (from Akbari's family home), on which we hear the beginning of Forugh Farrokhzad's poem Born Again (1982), from which in turn the film takes its title. Next, Akbari describes her family life before the journey through Dubai and Stockholm to London. The images illustrate what Akbari narrates, and the words reflect on the images shown. Those from Dubai portray the contradiction between the image of western women associated with advertising and the situation of women in the country. Akbari reflects on the lack of freedom, materialising female intersubjectivity:

Beyond the façade, the emptiness is infinite. There is no freedom, there is no democracy $[\ldots]$ They believe there is no difference between women who are forced by society to pursue beauty at all cost and women who are forced to wear a chador. Both situations are impossible to endure.

In Sweden, the filmmaker opposes the old family images with the pictorial images of the visited museums, several of them around the female portrait and the nude. Female experience, shared with another woman friend, is then linked to the exile experience, offering a reflection about female exile: "That profound awareness of something haunting 
us [...] Often we search for joy in the trivial things of life, and discover only art can bind us to the vital roots of existence." In London, Akbari takes up the images from the shop windows, similar to those portrayed in Dubai. Having established her residence in this city, the filmmaker invites Cousins to meet her, and then the moving image emerges, with its direct sound, of herself in her new home, doing daily tasks: "I contemplate what's happened to me and what is going to happen to me." The filmmaker then takes up the still images to show the moving of her belongings that travel from Tehran to London; objects that represent her existence: "Mark, these boxes will be waiting for your hands and mine to reveal their secrets, blow away their dust and place them onto new shelves." Akbari adds that she would like to take him to the house of Ibrahim Golestan, producer of The House is Black (1962), the only film directed by Farrokhzad: "The film made by the woman whose name is tattooed on your arm." A still image allows us to contemplate both filmmakers together, in which Akbari shows Cousins' tattoo to the camera, whose nature is very different from the one we will later contemplate on the filmmaker's body. Next, on the black image, Farrokhzad's poem continues to end the letter. Akbari's second and last missive creates a nude self-portrait that is irretrievably linked to motherhood and cancer, the latter narrated in her documentary film $10+4$ (2007); a film conceived as the continuation of Ten (Abbas Kiarostami, 2002) in which Akbari was the protagonist. Her voice-over is now accompanied by the video image in which she will show her body. The images of Akbari taking a bath alternate with different still images. First of all, three Iranian miniatures through which Akbari reflects on the meaning of the nude in her culture. Finally, images of mosques through which the filmmaker reflects on the sensuality of its architecture. And all of them, facing the body of Akbari naked, submerged in the water or emerged from it: "My body's voice is the voice of guilt." The water covers Akbari's torso, which she washes with her hands, hiding and revealing the 
double mastectomy suffered: "I lost a part of my body. It was like crossing a border and leaving something behind. Here I was force to sacrifice a part of my body in order to save my body, my life." The filmmaker shows a new scar on her body, that of a caesarean section, covered by a tattoo: "My body is my country and it's constantly changing." Then, the image of the bathtub emptying of water becomes a powerful metaphor for the void Akbari talks about: "Mark, I don't know who I am. Do you know who you are?" The filmmaker concludes her letter with one last image (Figure 4):

I write on my body for you. Mark, I am getting ready to go back to Virginia Woolf's house to take another photo in the same position. Mark, I've never taken a nude picture before. I have no idea how my body will look. Mark, I wrote the novel Orlando by Virginia Woolf on my body in Farsi; a body which has many stories of its own. If my body could talk, she would scream. I stood in front of her house in the same position and took this photo for you and everybody.

Figure 4. Life May Be (Mania Akbari and Mark Cousins, 2014) (C Hibrow Productions. Courtesy of the filmmaker.

This powerful image of Akbari's naked body, testimony of different mutations, becomes a feminist vindication of her past and present and transcends cultural boundaries: The text of Orlando. A Biography (1928) translated into Farsi and written on Akbari's skin, symbolises the struggle of women in all domains of their existence. Akbari continues her work within the epistolary practice in her next film, A Moon for My Father (2019), a filmic correspondence with his partner, the sculptor Douglas White. A short prologue shows us again Akbari's naked body in December 2013, at a hospital visit, giving way to five letters, three from her and two from him, which tell us the evolution of their relationship focusing in the concept of skin: those of White's sculptures (bats and elephants) and that of Akbari's body: "I 
believe that the most profound physical level of human beings is their skin [...] the deeper part of my existence, the skin of my breasts."

In her first letter, March 2014, Akbari relates White's rubber palm trees sculptures to the Iranian ones suffering the Iran-Iraq war (1980-1988) as a symbol of her scared childhood: "If they could talk, they'd have hundreds of stories to cry out. Memories of the massacre of women, men and children, of homelessness... of injuries... of starvation." White's sculpture finds then an astonishing real reference which turn also into a metaphor of Akbari's mutilated childhood because of war. Her second letter, February 2015, is born from the reflection about the reason why both correspondents are afraid of starting a relationship, of endings and losses. Akbari relates the images of her underground daily trips, and the anonym presences, to the narrative of her family losses, her uncle and her cousin: "as a child I also had heroes who left me." The first a military executed by the Islam revolution, the second a martyr of the latter in the bombing of the Iranian Parliament in June 1981. Both protagonists of Akbari's childhood love imaginary, a patriarchal one, oppose the present underground images. Islam culture about women's body is again exposed: "All my teenage memories and those of my body were mixed up with religious music and chants." Almost the second half of the film belongs to the fifth and last shared letter, from Akbari to Douglas in December 2017, in which she tells and shows her new body transformations. The epistolary addressee moves progressively from White to the spectator. The black screen accompanies a confession "Douglas, for 13 years I slept in my underwear to avoid touching my breasts. I did not even really look at them." Akbari decides to change the sign of her body scars, undergoing breast reconstructions and becoming herself a powerful living sculpture: "I decide to change this line of death into a line of life. I decided to build a new home for my soul," "a 
dialogue open up between me and my skin," also regarding women rights fight: "I have lived most of my live in Iran where the female body is a source of guilt and is constantly censored from the new, social media and practically everywhere." Akbari relates the Iranian women's fight against compulsory hiyab, standing on the electrical boxes on the streets. The government builds pyramids on them in order to prevent women from using them and the society builds wooden bases on them so that they can be used: "In my view this is one of the most important and historical works in women's fight for their rights and equally. I always think that all those women and I are united as one soul.” As in Life May Be, Akbari creates a powerful and committed image of women sisterhood. She puts her pregnant and naked body on one of those electrical boxes where Iranian women fight for their rights (Figure 5).

Figure 5. A Moon for My Father (Mania Akbari and Douglas White, 2019)

(c) Cryptofiction. Courtesy of the filmmaker.

But Akbari's resilience doesn't end there. Besides the possibility that her hereditary cancer could recur, the doctors decide to remove her ovaries and she makes another decision, a pregnancy: "After removing the ovaries, it was time for another major change." One more time, motherhood finally appears, in this case as the end of an extraordinary journey through Akbari's body mutilations and reconstructions, used to build a discourse of feminism, sisterhood and female intersubjectivity.

Transoceánicas offers the audiovisual correspondence of two filmmaker friends, Meritxell Colell Aparicio and Lucía Vassallo, after interposing an ocean of physical distance between them, from Barcelona to Buenos Aires. The spatial decalage contained in the title symbolises other emotional, sentimental and relational 
distances and absences. Twenty-five letters over more than four years create an exquisite experience of audiovisual intersubjectivity as a space, and time, in which to share the professional, the personal, the existential: "Letters are our way of sharing. To write to you is to review my own life. To try and be clearer, to connect with you and with myself," "I share with you the feeling of growing up." And this experience also shows its difficulties, its limits, its impossibilities even. Subjective time here becomes intersubjective time, the one perceived from the epistolary experience; their presences and absences, their expressions and their silences, their escapes and their returns. And to do so, the correspondents give meaning to the different possibilities of their epistolary enunciation.

The first letters seem to establish an enunciation choice. The images from both filmeures avoid the self-portrait and the epistolary texts are inscribed as subtitles. However, towards the middle of the correspondence, both enunciations become intimate expressions of an intersubjectivity under construction. Thus, the moving tenth letter, from Colell Aparicio, addressing her three-year silence, includes the beginning of her self-filming -through a mirror first, that of her shadow on the apartment walls after- and finally the portrait: "Nuria manages to take a decent one [picture of myself]. And there it is. That gaze, that photo, is a turning point for me." Once again, female intersubjectivity makes identity reaffirmation possible. Then, Vassallo's answer interrupts Colell Aparicio's letter, shifting the correspondence to the desired dialogue, to include the direct sound of her voice behind the camera as epistolary enunciation. In the second part of the correspondence, from the thirteenth missive, the different expressions of the correspondents' voices make possible essential reinterpretations of their previous absence. Vassallo's first pregnancy turn the self-portrait, also including her voice, into a missive to the future baby and to 
Colell Aparicio, and then the letter shifts to the subtitles to narrate the abortion suffered. The pain of a second pregnancy and abortion intensifies the need, already present in the letters, to make of them a gift-shipment, thus materialising the conception of Varda's audiovisual postcards, analysed by Bluher, of which we find many examples of a poetic nature: "Here are some flashes of beauty. Images that make me dream." Those Mekasian glimpses make a deeper sense when becoming intimate gifts for the suffering friend. Colell Aparicio's need to accompany hers also causes the appearance of her voice, first as voice-over, to talk about the dreams responsible of the oneiric nature of many of her epistolary images: "Lulu, you know I am not a friend of putting my voice in stuff, but I'll stop hiding behind texts." Later, her voice behind the camera appears for the first time to generate a kind of the synthesis-moment of the correspondence. She shows the Super-8mm rolls that she gets revealed after Vassallo's request to retrieve lost files. They contain images filmed a decade earlier that stayed hibernated and now Colell Aparicio is not only going to film their projection, but her first viewing of them. Her voice shows her spontaneous reactions to those forgotten images. The audiovisual missive then reveals its specific and unique nature, its deepest possibilities. And the distinctive use between voice and subtitles also makes sense (Figure 6):

I've been thinking how much your letters question me and make me grow. How our friendship has grown thanks to the cinema $[\ldots]$ So for my next letter I'll try not to hide anymore. I'll try to talk to you like when we're together $[\ldots]$ Thanks for getting me close to my own footage.

Figures 6. Transoceánicas (Meritxell Colell Aparicio and Lucía Vassallo, 2020) (C) Intropia Media, Hellish Producciones Cinematográficas, Pensilvania Films. Courtesy of the filmmakers. 
Therefore, not only does friendship grow thanks to cinema, but the cinema of both filmmakers grows thanks to their friendship. Vassallo offers another profound characterization of this audiovisual epistolary space-time in her following letter: a self-filming in front of the mirror, offering that writing degree zero of audiovisual epistolary enunciation with which Mekas already delighted us in his correspondence with Jose Luis Guerin (Monterrubio Ibáñez 2019b). The audiovisual epistolary nature in its deep essentiality: 'I'm here to be with you. I don't feel like talking much."

This female intersubjectivity also recognises and explores the distances, in this case around motherhood, whose Vassallo's desire takes her to a painful process of abortions and finally a successful egg donation; and before which Colell Aparicio tries to fight her incomprehension with empathy, also using her voice. Once again motherhood, but this time also explored from the absence of its desire and the lack of understanding about its limits. Once again, the grandmother as an essential figure of the memory to preserve. The portrait of Colell Aparicio's grandmother configured along the letters crystallises in her recitation of a children tale, through which she also takes on a voice, offering women's vindications regarding female relatives.

That "friends in cinema" from Mekas - to whom Colell Aparicio pays intimate tribute- to Guerin finds here its highest expression in the scarce history of filmic correspondences. And it is not by chance that it occurs in the first correspondence between women filmmakers, thanks to the capacity of sisterhood to explore intersubjectivity in a profound way. The evolution of the presence of women filmmakers in epistolary enunciation is contained from that fictional epistolary friendship conceived by Varda in 1977 and this filmic correspondence between filmmaker friends more than forty years later. Colell Aparicio's and Vassallo's 
professional experience is also essential in the correspondence. The place in the world they seek is also their places in cinema, which are accompanied, and helped, by their place in friendship, in the female intersubjectivity they exercise.

\section{Conclusion}

This itinerary through letter-films and filmic correspondences by women filmmakers allows to draw several conclusions. First, their relevance in the innovation and evolution of epistolary enunciation is evidenced. They explore the seriality and materiality of the epistolary device and the stratification of its audiovisual modality. Second, how they use it in a truly fruitful way in order to explore not just alterity, paradigmatic concept of postmodernity inherent to the epistolary device, but female alterity and intersubjectivity: "Thinking of intersubjectivity as interrelation would therefore be to agree to make oneself, at all times, the subject of this plurality of perspectives" (Thomas-Fogiel 2014, 386).

Turning Duras' fictional epistolary variations into autobiography, Tiziana Panizza and Jeannette Muñoz offer almost unique creations of epistolary seriality, which deepen the epistolary temporality. Besides, they explore epistolary materiality in relation with an aesthetics of glimpses. Panizza uses both concepts to deep identity through the female alterity of the grandmother, in order to explore exile and memory. And she also looks into the identity transformation due to motherhood. Muñoz utilises both concepts to explore intersubjectivity, especially regarding the concept of cinema community, offering a new realisation of the epistolary gift analysed in Varda's works. Petra Costa, for her part, makes the letter-film a unique exercise of intimate female alterity through the impossible dialogue with her absent sister transformed into a search for a self-portrait. The letter becomes the perfect tool to explore the alterity of consciousness that allows to overcome 
trauma. Childhood and adulthood, motherhood and sisterhood can dialogue as essential perspectives of female alterity.

Through filmic correspondences, Varda's fictional epistolarity becomes real. Women filmmakers explore both emotion and reflection. Naomi Kawase offers two identity portraits with a thirteen-year gap that allow to realise the identity evolution from a spontaneous and emotional youth to a more reflexive adulthood defined by motherhood and the intersubjective exercise with her son. So Yong Kim stays in the frontier between the shipment and the letter in order to also explore that intimate intersubjectivity, from the unborn child to the family identity. Mania Akbari focuses on her own body to offer both an identity self-portrait and a female intersubjective reflection on womanhood and sisterhood. Finally, Meritxell Colell Aparicio and Lucía Vassallo realise a correspondence between women filmmakers that brings together all the elements used by their colleagues and deepens female intersubjectivity exploring also its limits, bringing to the non-fictional and audiovisual space the experience represented by Varda more than forty years ago. These practices of women's epistolary cinema gravitate around the intimate experience of female alterity and intersubjectivity. Grandmothers, mothers and motherhood, sisters and sisterhood, and friends are essential to reflect on women's identity thanks to the epistolary device.

\section{References}

Agudo, Vanesa; Francisco Algarín Navarro; and Blanca García. 2017. "Entrevista a Jeannete Muñoz." In Jeannette Muñoz. El paisaje como un mar, edited by Francisco Algarín Navarro, 29-72. Barcelona: Asociación Lumière.

Augé, Marc. 1992. Non-lieux. Introduction à une anthropologie de la surmodernité. Paris: Éditions du Seuil. 
Balló, Jordi. 2014. "Las correspondencias como herencia literaria aplicada al cine.” In Littérature et cinema. Allers-retours, edited by Brice Castanon-Akrami; Françoise Heitz; Emmanuel Le Vagueresse and Catherine Orsini- Saillet, 313-321. Bruxelles: Orbis Tertius.

Bauman, Zygmunt. 1991. Modernity and Ambivalence. Cambridge: Polity Press-

Bluher, Dominique. 2019. "Varda's Gift of Postcards." Área Abierta. Revista de comunicación audiovisual y publicitaria 19 (3): 287-306.

https://dx.doi.org/10.5209/arab.62913

Broomer, Stephen. 2017. “The Gift-Culture of the Underground: Jeannette Muñoz's Envíos." In Jeannette Muñoz. El paisaje como un mar, edited by Francisco Algarín Navarro, 126-128. Barcelona: Asociación Lumière.

Català Domènech, Josep Maria. 2019. "Formas de la aparición. La carta fílmica como enigma." Área Abierta. Revista de comunicación audiovisual y publicitaria 19 (3),: 267286. https://dx.doi.org/10.5209/arab.61942

Depetris Chauvin, Irene. 2017. "Hilvanando sentimientos. Políticas de archivo e intensificación afectiva en Seams (de Karim Aïnouz) y en la trilogía Cartas visuales (de Tiziana Panizza)." Imagofagia. Revista de la Asociación Argentina de Estudios de Cine y Audiovisual 16: 439- 464.

DeRoo, Rebecca. 2009. "Confronting Contradictions: Genre Subversion and Feminist Politics in Agnès Varda's L'une chante, l'autre pas." Modern \& Contemporary France 17(3): 249-265. https://doi.org/10.1080/09639480903037111

Duras, Marguerite and Dominique Noguez. (984. La couleur des mots. Entretins avec Dominique Noguez Autour de huit films. Paris: Benoit Jacob.

Fanderl, Helga. 2017. “Envios.” In Jeannette Muñoz. El paisaje como un mar, edited by Francisco Algarín Navarro, 148-150. Barcelona: Asociación Lumière. 
Flitterman-Lewis, Sandy. 1996. To Desire Differently: Feminism and the French Cinema. New York: Columbia University Press (originally published 1990).

Grennberger. Martin. 2017. “Notes on Jeannette Muñoz.” In Jeannette Muñoz. El paisaje como un mar, edited by Francisco Algarín Navarro, 164-165. Barcelona: Asociación Lumière.

Hottell, Ruth. 1999. "Including Ourselves: The Role of Female Spectators in Agnes Varda's Le Bonheur and L'une chante, l'autre pas." Cinema Journal 38(2): 52-71.

Ishaghpour, Youssef. 1986. Cinéma Contemporain. De ce côté du miroir. Paris: Éditions de la Différence.

Kristeva, Julia. 1988. Étrangers à nous-mêmes. Paris: Librairie Artheme Fayard. Lagos Labbé, Paola. 2015. "El súper 8 mm como imagen intersticial en la Trilogía Cartas Visuales, de Tiziana Panizza." In Nuevas travesías por el cine chileno y latinoamericano, edited by Mónica Villarroel, 159-167. Santiago de Chile: Editorial LOM.

Marks, Laura U. 2000. The Skin of the Film: Intercultural Cinema, Embodiment and the Senses. Durham: Duke UP.

Monterrubio Ibáñez, Lourdes. 2018. De un cine epistolar. La presencia de la misiva en el cine francés moderno y contemporáneo. Santander: Shangrila Ediciones. Monterrubio Ibáñez, Lourdes. (ed.) 2019a. La enunciación epistolar en el cine contemporáneo / Epistolary Enunciation in Contemporary Cinema. Monographic issue. Área Abierta, 19(3) https://revistas.ucm.es/index.php/ARAB/issue/view/3535 Monterrubio Ibáñez, Lourdes. 2019b. "Friends in cinema. Correspondencias fílmicas; de la subjetividad a la intersubjetividad." Área Abierta. Revista de comunicación audiovisual y publicitaria 19(3): 439-470. https://dx.doi.org/10.5209/arab.65384 
Monterrubio Ibáñez, Lourdes. 2019c. "Los filmeurs Joseph Morder y Alain Cavalier. Gesto fílmico de despojamiento y epistemología de la no manipulación.” Arte, Individuo y Sociedad 31(1): 55-73 http://doi.org/10.5209/ARIS.58613

Naficy, Hamid. 2001. An Accented Cinema: Exilic and Diasporic Filmmaking. New Jersey: Princeton University Press.

Peirano, María Paz. 2018. "Domestic Films. Home and cultural memory in Tiziana Panizza's trilogy of film letters." Journal of Romance Studies, 18(2), pp. 227-250. https://doi.org/10.3828/jrs.2018.15

Petrus, Anna, 2011. “In Between days. Pequeñas revelaciones de lo íntimo, lo efímero y lo invisible." In Todas las cartas. Correspondencias fílmicas, edited by Jordi Balló, 170180. Barcelona: CCCB / Intermedio.

Renov, Michael. 2004. The Subject of Documentary. Minneapolis: University of Minnesota Press.

Ricœur, Paul. 1990. Soi-même comme un autre. Paris: Éditions du Seuil.

Russell, Catherine. 1999. "Autoethnography: Journeys of the Self” In Experimental Ethnography, 275-314. Duham: Duke University Press, pp. 275-314.

Thomas-Fogiel, Isabelle. 2014. 'L'intersubjectivité : perspectives philosophiques et philosophie des perspectives." In L'intersubjectivité en questions, edited by Christiane Moro, Nathalie Muller Mirza and Pascal Roman, 349-389. Lausanne: Éditions Antipodes. Voisin-Atlani, Françoise. 1988. “L’instance de la lettre.” In La lettre. Entre réel et fiction, edited by Jürgen Siess, 97-107, Paris: SEDES. 